\title{
Modifikasi Alat Pemecah Telur (EZ Cracker) untuk Skala Produksi Rumahan
}

\section{Modified Egg Breaker (EZ Cracker) for Production Home Scale}

\author{
Masri, Program Studi Pendidikan Teknologi Pertanian Fakultas Teknik Universitas Negeri \\ Makassar. Email: masri.hairuddin29@gmail.com \\ Lahming, Program Studi Pendidikan Teknologi Pertanian Fakultas Teknik Universitas Negeri \\ Makassar. Email: lahmingmaja@gmail.com \\ Jamaluddin, Program Studi Pendidikan Teknologi Pertanian Fakultas Teknik Universitas \\ Negeri Makassar. Email: mamal_ptm@yahoo.co.id
}

\begin{abstract}
Abstrak
Telur harus dipisahkan dari cangkangnya sebelum digunakan untuk keperluan tertentu. Saat ini telah ada teknologi tepat guna alat pemecah telur yang di sebut dengan EZ Cracker yang diproduksi di China. Namun, kekurangan dari alat ini yaitu hanya mampu memecahkan satu buah telur setiap alat digunakan. Dari permasalahan tersebut diperlukan sebuah inovasi baru yaitu dengan melakukan modifikasi alat pemecah telur. Penelitian ini bertujuan untuk memodifikasi alat pemecah telur agar lebih efektif dan efesien. Bentuk penelitian ini adalah modifikasi alat. Metodologi pengujian dilakukang dengan 10 kali ulangan. Setiap ulangan memecahkan 5 butir telur. Selama pengujian dilakukan perhitungan waktu dan jumlah telur yang dipecahkan secara sempurna. Hasil penelitian menunjukkan bahwa alat pemecah telur memiliki unjuk kerja secara efektif yaitu 270 butir/jam sedangkan secara manual diperoleh kapasitas efektif 304 butir/jam. Sehingga penggunaan alat yang dimodifikasi tidak terlalu efektif jika dibandingkan secara manual. Hal ini diakibatkan beberapa faktor seperti proses pemasukan bahan, posisi mata pisau, posisi telur yang kurang baik, dan ukuran bahan yang digunakan serta adanya telur yang tidak pecah sempurna saat pengujian. Namun alat ini cukup efisien karna pada saat memecahkan telur tangan tidak bersentuhan langsung dengan telur, bisa menggunakan tangan kiri maupun kanan, bisa digunakan semua kalangan umur, bisa memisahkan putih dan kuning telur, serta waktu pemecahan yang tidak jauh berbeda dengan cara manual.
\end{abstract}

Kata Kunci : Telur, Modifikasi, Efektif, Efisien.

\begin{abstract}
Eggs must be separated from the shell before being used for certain purposes. At present there is an appropriate technology for egg-breaking device called EZ Cracker which is produced in China. However, the drawback of this tool is that it is only able to crack one egg per tool used. From these problems a new innovation is needed, namely by modifying the egg-breaking device. This study aims to modify the egg-breaking device to make it more effective and efficient. The form of this research is a tool modification. The testing methodology was carried out with 10 replications. Each test broke 5 eggs. During the test the calculation of the time and number of eggs to be solved is perfect.The results showed that the egg-breaking device had an effective performance of 270 hours while manually obtained an effective capacity of 304 hours. So that the use of a modified tool was not very effective when compared manually. This is caused by several factors such as the process of insertion of material, the position of the blade, the position of the egg is not good, and the size of the material used and the presence of eggs that are not broken when perfect testing. This device iss quite efficient because when
\end{abstract}


cracking eggs, hands do not directly touch the eggs, can use your left or right hand, can be used by all ages can separate the white and egg yolk, and the time of solving is not much different from the manual method.

Keywords: Eggs, Modifications, Effective, Efficient.

\section{Pendahuluan}

Telur merupakan salah satu makanan yang tidak asing lagi bagi penduduk Indonesia, hal ini dikarenakan telur sangat mudah ditemui di kota - kota besar maupun di pedesaan khususnya yang memiliki peternakan unggas. Sebagai informasi, konsumsi telur ayam ras sepanjang periode 1987-2017 rata-rata naik 3,57\%/tahun. Pada 1987, konsumsi telur ayam ras hanya 2,55 $\mathrm{kg} / \mathrm{kapita} /$ tahun dan meningkat menjadi 6,53 $\mathrm{kg} / \mathrm{kapita} /$ tahun.Populasi ayam ras selama periode 2013-2017 diprediksi rata-rata naik 3,28\%/tahun dan dalam lima tahun kedepannya diprediksi naik rata-rata 5,54\%. Sementara produksi telur ayam ras selama lima tahun (2018-2021) diprediksi akan meningkat rata-rata sebesar 4,87\%/tahun sedangkan konsumsi rata-rata akan naik 4,18\%/tahun (Kementrian Pertanian RI, 2018). Produk dari unggas ini juga memiliki nilai gizi yang cukup tinggi karena mengandung zat makanan yang sangat dibutuhkan oleh tubuh manusia (Yuwanta, 2010). Telur banyak diminati oleh masyarakat karena murah dan mudah diperoleh. Telur salah satu bahan pangan dengan nilai nutrisi yang baik. Hal ini karena telur merupakan sumber protein yang terdiri dari berbagai asam amino yang dibutuhkan oleh tubuh. Menurut Sarwono (1995) bahwa pentingnya telur sebagai bahan makanan karena banyaknya zat pembangun (protein) yang terdapat didalamnya dan telur juga merupakan bahan makanan yang paling mudah dicerna.

Telur biasanya dikonsumsi oleh masyarakat sebagai makanan pokok atau digunakan sebagai bahan tambahan pada beberapa produk olahan pangan yang lain. Telur harus dipisahkan dari cangkangnya sebelum digunakan untuk keperluan tertentu.

Pada umumnya memecahkan telur secara manual sudah dianggap biasa dalam kehidupan masyarakat. Akan tetapi terkadang terjadi beberapa kesalahan atau kekurangan yang dilakukan masyarakat ketika memecahkan telur secara manual, diantaranya kulit telur yang pecah tidak beraturan, adanya serpihan cangkang telur yang masuk ke adonan, telur yang jatuh diluar wadah yang disediakan, dapur menjadi tidak teratur dan tangan menjadi kotor. 
Saat ini telah ada teknologi tepat guna alat pemecah telur yang di sebut dengan $E Z$ Cracker yang diproduksi di China. Suatu alat pemecah telur yang dibuat khusus tanpa bersentuhan langsung dengan telur tersebut. Kekurangan dari alat ini yaitu hanya mampu memecahkan satu buah telur setiap alat $E Z$ cracker ditekan, kemudian telur dimasukkan kembali secara manual, sedangkan kondisi masyarakat dalam hal mengolah makanan yang berhubungan dengan telur terkadang membutuhkan lebih dari satu telur. Untuk meningkatkan efektivitas dan efisiensi alat tersebut diperlukan sebuah inovasi baru yaitu dengan melakukan modifikasi alat pemecah telur (EZ Cracker) dengan menambah kapasitas kerja dari alat tersebut.

Diharapkan dengan modifikasi alat pemecah telur ini mampu memberikan kontribusi yang baik terhadap kemajuan teknologi tepat guna dalam hal pemenuhan kebutuhan alat-alat pengolahan bahan pangan, khususnya telur.

Tujuan penelitian ini untuk memodifikasi alat pemecah telur skala produksi rumahan agar lebih efisien dan efektif.

\section{Metode Penelitian}

Bentuk penelitian ini adalah penelitian rekayasa/rancang bangun. Penelitian ini akan mengembangkan produk yang telah ada yang dapat dipertanggungjawabkan.

\section{Waktu dan tempat}

Pembuatan dan pengujian alat dilaksanakan pada bulan Agustus September 2019 dan dilaksanakan di Laboratorium Pendidikan Teknologi Pertanian Fakultas Teknik Universitas Negeri Makassar.

\section{Desain Rancangan}

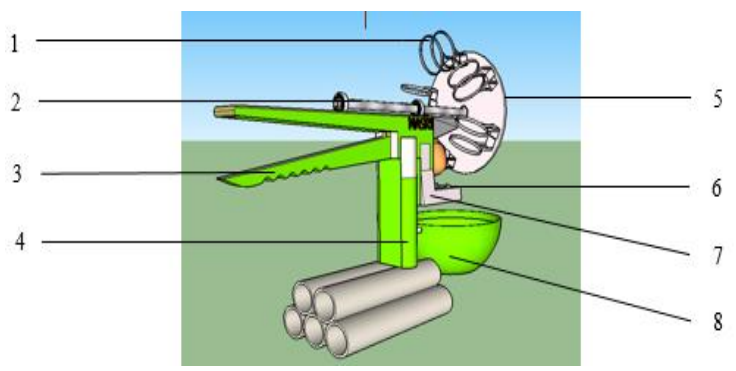

\section{Gambar 1. Desain Rancangan Alat}

Keterangan :

1. Tempat telur

2. Poros

3. Tuas Pemecah

4. Dudukan Alat

5. Roda Putar Tempat Telur

6. Pisau Pemecah Cangkang

7. Pembelah Cangkang

8. Pemisah Putih Telur

\section{Alat dan bahan}

Alat yang digunakan adalah Mistar siku, Cutter acrylic, Tang, Pisau, Kamera, Alat tulis menulis, Sarung tangan, Jangka Lingkaran, Obeng, Pensil, Kertas amplas, Gergaji ukir, Jangka lingkaran dan Busur 
sudut. Sedangkan bahan yang digunakan yaitu Plastik PP yang aman untuk makanan, Pisau stainless steel, Per pegas tarik ukuran kecil, Plastik akrilik, Laher atau Bearing 608 dan Aluminium.

\section{Prosedur Penelitian}

Menyiapkan alat dan bahan yang akan digunakan dalam proses perakitan. Selanjutnya merakit seluruh komponen alat sesuai sketsa gambar yang telah dibuat. Setelah alat sudah jadi maka selanjutnya dilakukan pengujian.

Pengujian dilakukang dengan cara 10 kali pengulangan. Setiap pengulangan memecahkan telur sebanyak lima butir. Selama pengujian dilakukan perhitungan waktu dan jumlah telur yang dipecahkan secara sempurna.

\section{Parameter Penelitian}

Menguji Fungsional Komponen Alat

Uji Fungsional dilakukan untuk mengetahui keuntungan mekanis pada saat alat digunakan. Untuk memperoleh besar kuasa yang diperlukan untuk menekan beban digunakan rumus pesawat sederhana:

$F \times l k=w \times l b$

$\frac{w}{F}=\frac{l k}{l b}$

Perbandingan antara berat beban dengan gaya kuasa disebut dengan keuntungan mekanis (KM).
$K M=\frac{w}{F}=\frac{l k}{l b}$

Keterangan :

$\mathrm{TB}=$ Titik Beban

$w$ = tempat beban

$\mathrm{TT}=$ Titik Tumpu

TK = Titik Kuasa

$F \quad$ = gaya bekerja

$L k=$ lengan kuasa

$l b=$ lengan beban

Menghitung Kapasitas Input Alat (KIA)

Pengukuran input alat dilakukan dengan membagi jumlah telur yang dipecahkan dengan waktu tertentu atau dapat dihitung dengan rumus sebagai berikut

$\mathrm{KIA}=\frac{\text { jumlah telur yang dipecahkan }}{\text { waktu pemecahan }}($ butir/detik $)$

Menghitung Kapasitas Efektif Alat (KEA)

Efektivitas alat dilakukan dengan tujuan untuk mengetahui keluaran yang diharapkan dari jumlah masukan atau input. $\mathrm{KEA}=\frac{\text { jumlah telur yang pecah sempurna }}{\text { waktu pemecahan }}$ (butir/detik) $(\mathbf{4})$

\section{Rendemen}

Rendemen bertujuan untuk menentukan hasil bersih dari kerja alat pemecah telur. Rendemen dapat dihitung dengan persamaan :

Rendemen $=\frac{\text { jumlah telur yang pecah sempurna }}{\text { total telur yang dipecahkan }} \times 100 \%(\mathbf{5})$ 
Presentase Keberhasilan dan Kerusakan Hasil Alat

Pengukuran persentase keberhasilan alat dapat ditentukan dengan membagi jumlah telur yang pecah sempurna dengan jumlah total telur yang dipecahkan tiap pengulangan kemudian dikali $100 \%$. Begitupun dengan kerusakan hasil yang dibagi adalah telur yang tidak pecah sempurna. Secara matematis dapat dituliskan dengan persamaan sebagai berikut:

PPS $(\%)=\frac{\text { Jumlah pecah sempurna }}{\text { total telur yang dipecahkan }} \times 100 \%$

PPTS $(\%)=\frac{\text { Jumlah tidak sempurna }}{\text { total telur yang dipecahkan }} \times 100 \%$

Keterangan:

PPS $=$ Presentase Pecah Sempurna

PPTS $=$ Presentase Pecah Tidak Sempurna

\section{Keseragaman Data Pemecahan}

Keseragaman data pemecahan dapat ditentukan dengan persamaan:

$S D($ Standar Deviasi $)=\sqrt{\frac{\sum_{i=1}^{n}(x i-\bar{x})^{2}}{(n-1)}}$

dengan :

$X i=$ Nilai data

$\bar{x}=$ Nilai Rata-rata data

$\mathrm{n}=$ Jumlah data

$$
\text { CV (Koefisien Keseragaman ) }: \frac{\mathrm{SD}}{\bar{x}} \times 100
$$

dengan :

$\mathrm{SD}=$ Standar Deviasi

$\bar{x}=$ Nilai Rata - rata data

\section{Hasil dan Pembahasan}

\section{Deskripsi Produk yang Dihasilkan}

Modifikasi alat pemecah telur skala industri rumah tangga telah dibuat berdasarkan gambar desain produk yang telah direncanakan.

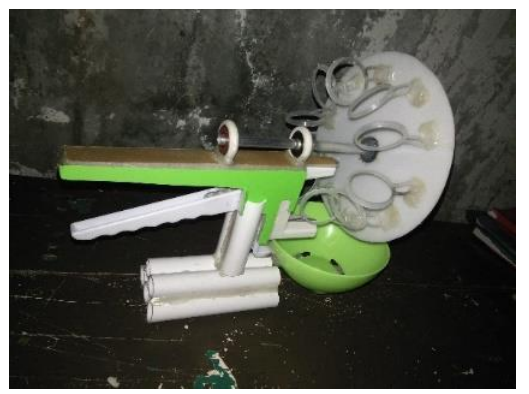

\section{Gambar 2. Alat pemecah telur secara keseluruhan}

\section{Hasil Pengujian Alat}

\section{Uji fungsional komponen alat}

Dari hasil perhitungan rumus Keuntungan Mekanis diperoleh besar gaya kuasa yang diperlukan untuk menekan beban yaitu $0,33 \mathrm{~N}$ sedangkan nilai keuntungan mekanis yang diperoleh sebesar 1,75. Sehingga gaya yang dibutuhkan untuk memecahkan telur (beban) lebih kecil dibandingkan dengan berat beban tersebut. 
Tabel 1. Data Pengujian Pemecahaan Telur

\begin{tabular}{|c|c|c|c|c|c|c|c|c|}
\hline Ulangan & $\begin{array}{l}\text { Telur yang } \\
\text { dipecahkan } \\
\text { (Butir) }\end{array}$ & $\begin{array}{c}\text { Waktu } \\
\text { Pemecahan } \\
\text { ( Detik) }\end{array}$ & $\begin{array}{c}\text { Waktu } \\
\text { dalam } \\
\text { Satuan } \\
\text { Jam }\end{array}$ & $\begin{array}{l}\text { Telur } \\
\text { yang } \\
\text { utuh } \\
\text { (Butir) }\end{array}$ & $\begin{array}{l}\text { Telur } \\
\text { yang } \\
\text { rusak } \\
\text { (Butir) }\end{array}$ & $\begin{array}{c}\text { Kapasitas } \\
\text { Input } \\
\text { (Butir/Jam) }\end{array}$ & $\begin{array}{c}\text { Kapasitas } \\
\text { Efektif } \\
\text { (Butir/jam) }\end{array}$ & $\begin{array}{c}\text { Rendemen } \\
(\%)\end{array}$ \\
\hline 1 & 5 & 61 & 0,0169 & 5 & o & 295 & 295 & 100 \\
\hline 2 & 5 & 67 & 0,0186 & 4 & 1 & 269 & 215 & 80 \\
\hline 3 & 5 & 64 & 0,0178 & 4 & 1 & 281 & 225 & 80 \\
\hline 4 & 5 & 62 & 0,0172 & 5 & o & 290 & 290 & 100 \\
\hline 5 & 5 & 60 & 0,0167 & 5 & o & 300 & 300 & 100 \\
\hline 6 & 5 & 63 & 0,0175 & 5 & 0 & 286 & 286 & 100 \\
\hline 7 & 5 & 64 & 0,0178 & 4 & 1 & 281 & 225 & 80 \\
\hline 8 & 5 & 60 & 0,0167 & 5 & o & 300 & 300 & 100 \\
\hline 9 & 5 & 65 & 0,0181 & 5 & 0 & 277 & 277 & 100 \\
\hline 10 & 5 & 63 & 0,0175 & 5 & o & 286 & 286 & 100 \\
\hline Jumlah & 50 & 629 & 0,1747 & 47 & 3 & 2865 & 2699 & 940 \\
\hline $\begin{array}{c}\text { Rata - } \\
\text { rata }\end{array}$ & & 62,9 & 0,0175 & 4,7 & 0,3 & 286 & 270 & 94 \\
\hline SD & & & & & & 10,106 & 34,103 & 9,661 \\
\hline $\mathbf{C V}$ & & & & & & 3,528 & 12,637 & 10,278 \\
\hline
\end{tabular}

Sumber: Data Pengujian, 2019

Kapasitas input alat

Berdasarkan penelitian, kapasitas input rata - rata alat pemecah telur adalah sebesar 286 butir/jam. Hasil penelitian diperoleh kapasitas input alat yang berbeda - beda di setiap ulangan. Hal ini dikarenakan kebutuhan waktu yang berbeda - beda untuk setiap kali pemecahan. Semakin rendah waktu yang dibutuhkan untuk pemecahan maka kapasitas input yang dihasilkan akan semakin tinggi.

\section{Kapasitas efektif alat}

Berdasarkan hasil penelitian yang dilakukan diperoleh kapasitas efektif alat dengan beberapa ulangan sebesar 270 butir/jam. Sedangkan dengan cara manual diperoleh kapasitas efektif yaitu 304 butir/jam. Dari data yang diperoleh bahwa penggunaan alat yang dirancang tidak terlalu efektif dibandingkan dengan cara manual. Hal ini terjadi sebab beberapa faktor sehingga dapat mempengaruhi waktu pemecahan pada saat menggunakan alat. Namun keuntungan lainnya yaitu pada saat menggunakan alat tangan tidak bersentuhan langsung dengan isi telur, semua kalangan umur bisa menggunakannya, alat pemecah telur cukup ringan, bisa digunakan dengan tangan kiri maupun kanan, bisa memisahkan kuning dan putih telur, serta cangkang tidak jatuh ke wadah. Selain itu nilai perbandingan rata-rata waktu pemecahan selama pengujian 10 kali ulangan antara secara manual dengan penggunaan alat tidak terlalu besar yakni 3,6 detik (secara manual diperoleh rata-rata waktu 59,3 detik 
sedangkan penggunaan alat diperoleh 62,9 detik).

Pada pengujian alat didapatkan hasil kapasitas efektif alat berbeda - beda disetiap ulangan. Telur yang tidak tepat dikedudukannya atau posisi telur yang tidak sesuai dengan titik yang ditentukan saat menarik tuas serta posisi pisau yang kurang baik mengakibatkan pemecahan tidak sempurna menjadi faktor utama menurunnya kapasitas alat, kemudian beberapa kendala waktu diantaranya proses pemasukan telur dan pengeluaran cangkang telur dari kedudukannya juga mempengaruhi waktu produksi dan menurunnya kapasitas alat. Beberapa kendala tersebut dapat diatasi dengan meminimalkan waktu yang dibutuhkan pada saat pemasukan telur dan pengeluaran cangkang telur dari kedudukannya, serta memperbaiki posisi pisau pada saat setiap kali pemecahan sehingga diharapkan kapasitas alat yang diperoleh dapat lebih optimal. Hal tersebut sesuai dengan pendapat Smith dan Wilkes (1990) yang menyatakan bahwa kapasitas dari mesin atau alat bergantung pada banyak faktor, seperti laju pemasukan bahan, kecepatan putaran, posisi mata pisau, daya yang tersedia dan macam bahan yang digunakan.

\section{Rendemen}

Penentuan rendemen penelitian dilakukan 10 kali ulangan dengan setiap ulangan terdapat 5 telur yang pecahkan sehingga jumlah keseluruhan 50 telur yang akan dipecahkan (masih utuh), setelah dilakukan proses pemecahan dengan $10 \mathrm{kali}$ ulangan terdapat 47 telur yang pecah sempurna dan 3 telur yang tidak pecah sempurna, sehingga diperoleh rendemen rata - rata pemecahan sebesar $94 \%$.

Berdasarkan penelitian yang dilakukan untuk mendapatkan hasil rendemen terbaik perlu memperhatikan posisi telur pada wadah dan posisi titik pisau pemecah dengan sisi tengah cangkang telur serta keseragaman diameter telur. Alat kurang maksimal jika diameter telur $<41$ $\mathrm{mm}$ dan > $50 \mathrm{~mm}$. Rendemen juga berhubungan terhadap kerusakan hasil dari alat pemecah telur ini sebab semakin tinggi rendemen, maka nilai kerusakan hasil semakin rendah.

Presentase Keberhasilan dan Kerusakan Hasil

Indikator telur yang pecah sempurna yaitu cangkang telur terbelah secara baik dan isi telur jatuh ke wadah sesuai yang diinginkan. Sedangkan indikator telur yang tidak pecah sempurna yaitu cangkang telur hanya retak atau hanya sedikit yang pecah dan isi telur tidak jatuh ke dalam wadah. 
Tabel 2. Presentase Keberhasilan dan Kerusakan Hasil

\begin{tabular}{cccccc}
\hline Ulangan & $\begin{array}{c}\text { Jumlah telur } \\
\text { sebelum } \\
\text { dipecahkan } \\
\text { (Butir) }\end{array}$ & $\begin{array}{c}\text { Telur yang } \\
\text { utuh (Butir) }\end{array}$ & $\begin{array}{c}\text { Telur yang } \\
\text { tidak pecah } \\
\text { sempurna } \\
\text { (Butir) }\end{array}$ & $\begin{array}{c}\text { presentase } \\
\text { Telur yang } \\
\text { utuh (\%) }\end{array}$ & $\begin{array}{c}\text { Telur yang } \\
\text { tidak utuh } \\
\text { (\%) }\end{array}$ \\
\hline 1 & 5 & 5 & 0 & 100 & 0 \\
2 & 5 & 4 & 1 & 80 & 20 \\
3 & 5 & 4 & 1 & 80 & 20 \\
4 & 5 & 5 & 0 & 100 & 0 \\
5 & 5 & 5 & 0 & 100 & 0 \\
6 & 5 & 5 & 0 & 100 & 0 \\
7 & 5 & 4 & 1 & 80 & 20 \\
8 & 5 & 5 & 0 & 100 & 0 \\
9 & 5 & 5 & 0 & 100 & 0 \\
10 & 5 & 5 & 0 & 100 & 0 \\
\hline Jumlah & $\mathbf{5 0}$ & $\mathbf{4 7}$ & $\mathbf{3}$ & $\mathbf{9 4 0}$ & $\mathbf{6 0}$ \\
\hline Rata - rata & $\mathbf{5}$ & $\mathbf{4 , 7}$ & $\mathbf{0 , 3}$ & $\mathbf{9 4}$ & $\mathbf{6}$ \\
\hline SD & & & & $\mathbf{9 , 6 6 1}$ & $\mathbf{9 , 6 6 1}$ \\
\hline DV (\%) & & & & $\mathbf{1 0 , 2 7 8}$ & $\mathbf{1 6 1 , 0 1 5}$ \\
\hline
\end{tabular}

\section{Sumber: Data Pengujian, 2019}

Berdasarkan hasil penelitian yang telah dilakukan kerusakan hasil hanya terjadi pada ulangan 2, 3 dan 7 masing masing terdapat satu butir telur yang tidak pecah sempurna. Pada ulangan 1, 4, 5, 6, 8, 9 dan 10 seluruh telur pecah sempurna. Sehingga persentase keberhasilan hasil rata - rata yang diperoleh untuk 10 ulangan sebesar $94 \%$ sedangkan presentase kerusakan hasil sebesar $6 \%$.

Kerusakan hasil dipengaruhi beberapa faktor yaitu diameter telur yang terlalu kecil atau terlalu besar, ketebalan cangkang, pisau pemecah, posisi telur yang kurang baik serta kesalahan pengguna alat. Hal ini sesuai dengan pendapat Mohsenin (1980) yang menyatakan bahwa bentuk, ukuran, volume, kerapatan, porositas, kekerasan dan warna adalah beberapa masalah yang berkaitan dengan desain suatu alat atau mesin. Beberapa faktor tersebut dapat diatasi dengan cara memecahkan telur dengan ukuran yang sesuai dengan alat dan memastikan posisi telur sudah baik dan benar. Persentase keberhasilan dan kerusakan hasil dapat dilihat pada Tabel 2.

\section{Simpulan}

Pada penelitian yang dilakukan alat pemecah telur memiliki unjuk kerja secara efektif yaitu 270 butir/jam sedangkan secara manual diperoleh kapasitas efektif 304 butir/jam. Beberapa faktor yang mempengaruhi kinerja alat seperti peroses pemasukan bahan, posisi mata pisau, posisi 
telur yang kurang baik, dan ukuran bahan yang digunakan serta adanya telur yang tidak pecah sempurna saat pengujian. Alat ini cukup efisien karna pada saat memecahkan telur tangan tidak bersentuhan langsung dengan telur, bisa menggunakan tangan kiri maupun kanan, bisa digunakan semua kalangan umur, bisa memisahkan putih dan kuning telur, serta rata-rata waktu pemecahan yang tidak jauh berbeda dengan cara manual dengan selisih 3,6 detik selama 10 kali ulangan.

\section{Daftar Pustaka}

Mohsenin, N. 1980. Physical Properties of Plant and Animal Materials. New York: Gordon and Breach Science Pub.

Sarwono, 1995. Pengawetan dan Pemanfaatan Telur. Jakarta : Penebar Swadaya.

Smith, H. P. \& Wilkes. L. H. 1990. Mesin dan Peralatan Usaha Tani Edisi ke6. Diterjemahkan oleh Purwadi. Yogyakarta: Gadjah Mada University Press.

Yuwanta, T. 2010. Telur dan Kualitas Telur. University Press: Yogyakarta.

www.pertanian.go.id/berita/ Artikel Kementrian Pertanian: Konsumsi Telur Ayam Ras. Diakses pada tanggal 5 Desember 2019. 
Halaman ini sengaja dikosongkan 